\title{
DAMPAK PENINGKATAN HARGA PANGAN TERHADAP KESEJAHTERAAN RUMAH TANGGA DI WILAYAH RAWAN PANGAN SUMATERA
}

\author{
Nuri Nasriyah' ${ }^{1}$, Maulana Malik Sebdo Aji ${ }^{2}$
}

\begin{abstract}
This study aims to analyze the general picture of food consumption and food demand response to changes in income, prices, demographic variable, and the impact of rising food prices on household welfare in household food insecure areas of Sumatera. This study uses raw data obtained from 2018 The National Socio-Economic Survey (Susenas) BPS-Statistics. The sample comprises 12,606 households in Sumatera's food-insecure areas. A Quadratic Almost Ideal Demand System (QUAIDS) is employed to estimate price and income elasticities, as well as the impact of demographic and geographical factors on food demand patterns. Compensating Variation (CV) is used to estimate changes in household welfare due to an increase in food prices. Ten aggregate commodity groups were chosen for this analysis: rice; non-rice grains and tubers, fish, shrimp, squid, shellfish; meat; eggs and milk; vegetables, fruit and nuts; oil and coconut; prepared food; other consumption; and cigarettes and tobacco. The results show that the higher the increase in food prices, the more reduction in household welfare. The proportion of household expenditure in Sumatera's food-insecure areas is dominated by food consumption. The proportion of household food expenditure in Sumatera's food-insecure areas is still dominated by food expenditure. The income elasticity of all food groups is positive. Meanwhile, the value of the price elasticity of the entire food group is negative and to interpret it is absolute so it is positive. The value of cross-price elasticity varies between food groups. Income, price, and demographic variables except head of household sex and poverty status have an effect on the pattern of food consumption. An increase in food prices reduces household welfare. Policy advice for the government is to increase the income of the household in Sumatera food-insecurity area, maintain price stability or reduce food prices.
\end{abstract}

Keyword: food consumption pattern, food demand system, income elasticity, price elasticity, quadratic almost ideal demand system, food insecurity, compensating variation, welfare

\section{PENDAHULUAN}

Indonesia merupakan salah satu negara yang mengalami wabah penyakit COVID-19. Sampai tanggal 2 September 2020, terdapat sebanyak 25,90 juta jiwa kasus positif di seluruh dunia dengan angka kematian yang terjadi sebesar 0,86 juta jiwa sedangkan di Indonesia, terdapat 177, 57 ribu jiwa kasus positif dan kasus kematian sebesar 7.505 jiwa (https://www.worldometers.info/coronavirus). Dampak penyebaran COVID-19 semakin luas. Tidak hanya masalah kesehatan, wabah COVID-19 memengaruhi berbagai bidang seperti penurunan pertumbuhan ekonomi terkait sektor industri, perdagangan dan ekspor,

\footnotetext{
${ }^{1}$ Badan Pusat Statistik Kota Langsa, nurin@bps.go.id

2 Badan Pusat Statistik Provinsi Aceh, mmalik@bps.go.id
} 
penurunan daya beli masyarakat dan terganggunya pasokan serta permintaan pangan yang merupakan isu yang memerlukan penanganan segera.

Apabila dilihat dari sudut pandang pasokan, hal tersebut menjadi terganggu karena adanya upaya penahanan (karantina) yang membatasi mobilitas dan meningkatnya biaya usaha karena rantai pasokan yang tidak lancar. Selain itu, jika dilihat dari sudut pandang permintaan, terdapat penurunan juga karena tingginya ketidakpastian, upaya penahanan (karantina), serta meningkatnya biaya pengeluaran yang mengurangi kemampuan belanja. Lebih dari setengah pendapatan rumah tangga digunakan untuk kebutuhan pangan di negara berkembang sehingga fluktuasi harga secara tiba-tiba (Ivanic dan Martin 2008) dapat menyebabkan keadaan rawan pangan dan kemiskinan. Besarnya proporsi pengeluaran pangan membuat masyarakat rentan terhadap lonjakan harga komoditas pangan sehingga memengaruhi pola konsumsi.

Share inflasi pangan Indonesia menyumbang cukup tinggi terhadap inflasi umum Indonesia dengan nilai rata-rata share tahun 2011-2019 sebesar 58,36 persen (Badan Pusat Statistik 2012; 2014; 2015; 2016; 2017; 2018; 2019; 2020). Hal ini menyebabkan fluktuasi harga pangan dapat menimbulkan gejolak kesejahteraan masyarakat yang sangat berarti terutama masyarakat miskin karena sebagian besar pendapatannya digunakan untuk pangan. Kerawanan pangan dan kemiskinan merupakan sesuatu yang saling berkaitan (Booth dan Smith 2001). Masalah kemiskinan berhubungan erat dengan kerawanan pangan walaupun tidak identik (Badan Ketahanan Pangan Kementrian Pertanian, 2018). Kerawanan pangan dapat semakin memperdalam kemiskinan, tidak hanya menimbulkan efek negatif pada berkurangnya asupan nutrisi, kesehatan dan mata pencaharian tetapi rumah tangga bahkan dapat melakukan penjualan aset yang membuat rumah tangga tersebut lebih sulit untuk keluar dari kemiskinan (Harrigan, 2008).

Studi Mekonnen dan Gerber (2017) menyebutkan bahwa walaupun beberapa tahun mengalami perbaikan tetapi masalah kemiskinan dan kerawanan pangan tetap menjadi tantangan. Pangan merupakan kebutuhan dasar bagi kehidupan manusia tetapi masalah krisis dan kerawanan pangan masih menjadi masalah di banyak negara (Stezhko 2016; Hasibuan, Waromi, dan Utomo 2018) terutama di negara berkembang, termasuk Indonesia (Riptanti dkk. 2018).

Berbagai hal tersebut menyebabkan pemerintah harus tetap fokus dalam penyelenggaraan pangan terutama saat terjadi gejolak pada pasokan dan permintaan karena wabah COVID-19 ini. Menurut Undang-Undang Nomor 18 Tahun 2012 mengenai pangan, penyelenggaraan pangan adalah kegiatan perencanaan, pelaksanaan, dan pengawasan dalam penyediaan, keterjangkauan, pemenuhan konsumsi pangan dan gizi, serta keamanan pangan dengan melibatkan peran serta masyarakat yang terkoordinasi dan terpadu. Salah satu tujuan dari penyelanggaraan pangan yaitu mempermudah atau meningkatkan akses pangan bagi masyarakat, terutama masyarakat rawan pangan dan gizi.

Sumatera merupakan regional ekonomi terbesar kedua di Indonesia, sehingga kebijakan mengenai pangan penting bagi Sumatera. Penelitian ini perlu dilakukan dengan tujuan dapat menganalisis dampak peningkatan harga pangan terhadap kesejahteraan rumah tangga di wilayah rawan pangan Sumatera agar pemerintah dapat fokus terhadap penanganan kebijakan pangan di wilayah rawan pangan yang tentunya memerlukan perhatian lebih besar terhada pangan. Selain menganalisis gambaran umum konsumsi pangan rumah tangga di wilayah rawan pangan Sumatera, penelitian ini fokus pada permintaan pangan oleh rumah tangga di wilayah rawan pangan Sumatera, terutama respon permintaan pangan 
rumah tangga tersebut terhadap perubahan harga dan pendapatan, serta faktor-faktor demografi yang memengaruhinya.

\section{LANDASAN TEORITIS}

Pindyck dan Rubinfeld (2018) mengatakan bahwa teori perilaku konsumen menjelaskan bagaimana konsumen mengalokasikan pendapatan untuk pembelian berbagai barang dan jasa untuk memaksimalkan kesejahteraan. Pemahaman pengambilan keputusan konsumen dalam melakukan pembelian barang atau jasa diperlukan untuk membantu memahami bagaimana perubahan pendapatan dan harga memengaruhi permintaan barang dan jasa serta alasan permintaan beberapa produk lebih sensitif daripada yang lain terhadap perubahan harga dan pendapatan.

Permintaan menjelaskan perilaku konsumen mengenai bagaimana konsumen yang rasional membuat keputusan mengenai barang atau jasa yang akan dikonsumsi ketika dihadapkan dengan harga yang berbeda-beda dan anggaran yang terbatas (Mittal dan Council 2010).

Fungsi permintaan adalah fungsi yang menghubungkan pilihan optimal dan jumlah yang diminta dengan harga dan pendapatan yang berbeda (Varian 2014, 78). Deaton dan Muellbauer (1981, 37-38) menjelaskan bahwa terdapat dua pendekatan dalam fungsi permintaan, yaitu fungsi permintaan marshallian (uncompensated demand function) dan fungsi permintaan hicksian (compensated demand function). Fungsi permintaan marshallian menggunakan pendekatan marshallian berdasarkan jumlah permintaan barang atau jasa yang merupakan fungsi dari harga dan pendapatan. Prinsip dari marshallian adalah memaksimalkan utilitas dengan kendala anggaran sedangkan fungsi permintaan hicksian menggunakan pendekatan hicksian berdasarkan jumlah permintaan barang atau jasa yang merupakan fungsi dari harga dan tingkat kepuasan konsumen. Prinsip dari hicksian adalah meminimumkan pengeluaran (pendapatan atau anggaran) dengan utilitas konstan. Perubahan pendapatan diatur untuk mengkompensasi perubahan harga dengan tujuan menjaga tingkat kepuasan agar tetap sama.

Elastisitas mengukur sensitivitas suatu variabel terhadap variabel lainnya. Secara khusus, elastisitas merupakan angka yang menjelaskan perubahan persentase yang akan terjadi pada suatu variabel sebagai tanggapan terhadap peningkatan 1 persen pada variabel lain (Pindyck dan Rubinfeld 2018, 55). Terdapat tiga konsep elastisitas yang biasa digunakan untuk melihat respon konsumen individu dan pasar yaitu elastisitas harga sendiri, harga silang, dan pendapatan (Boediono 2012, 20 dan Pindyck dan Rubinfeld 2018, 55 dan 57).

Penelitian mengenai pola permintaan pangan di Indonesia antara lain penelitian Ritonga (1994), Rachman (2001), Sugiyanto (2006), Mauludyani, Martianto, dan Baliwati (2008), Suryani dan Rachman (2008), Pangaribowo (2010), Pangaribowo dan Tsegai (2011), Siagian (2013), Faharuddin, Mulyana, dan Yunita (2015), Sulistyaningrum (2016), Umam (2017), Arthatiani dan Kusnadi (2018), dan Setiana (2019).

Beberapa peneltian pola konsumsi pangan di luar negeri dilakukan baik di negara maju maupun berkembang antara lain penelitian Abdulai (2002), Abdulai dan Aubert (2004), Bopape (2006), Tey dkk. (2009), Fashogbon dan Oni (2013), Wang (2014), Ulubasoglu dkk. (2015), Hayat, Hussain, dan Yousaf (2016), Hoang (2018) serta Vu (2020).

Selain terkonsentrasi pada satu wilayah, terdapat penelitian yang membandingkan antar wilayah. Widodo (2004) membandingkan pola konsumsi rumah tangga Indonesia dan Jepang. Data untuk Jepang berasal dari laporan tahunan pendapatan dan pengeluaran keluarga tahun 1963 sampai 2004 sedangkan data Indonesia berasal dari Survei Biaya Hidup 
tahun 1980, 1981, 1984, 1987, 1990, 1993, dan 1996. Penelitiannya menunjukkan bahwa rumah tangga Indonesia lebih menyukai daging sedangkan rumah tangga Jepang lebih menyukai ikan. Tigkat kesejahteraan rumah tangga di Indonesia turun lebih banyak dibandingkan rumah tangga di Jepang dengan adanya peningkatan harga.

Variabel yang berpengaruh secara langsung terhadap pemodelan pola konsumsi pangan yaitu pendapatan dan harga (Varian 2014, 95) yang biasanya dijelaskan dengan analisis elasitisitas. Selain itu, menurut Pollak dan Wales (2015) variabel demografi perlu diikutkan dalam model sistem permintaan yang berguna untuk mengontrol variasi preferensi rumah tangga. Hasil dari beberapa penelitian mengenai pola konsumsi pangan berupa elastisitas pendapatan, harga, dan variabel demografi sebagai berikut:

1. Elastisitas Pendapatan

Elastisitas pendapatan hampir semua penelitian bernilai positif yang menunjukkan bahwa komoditas yang diteliti merupakan barang normal atau barang mewah kecuali penelitian Siagian (2013) dan Umam (2017).

\section{Elastisitas Harga}

Secara keseluruhan, hampir semua penelitian menghasilkan elastisitas harga sendiri negatif kecuali penelitian Ulubasoglu dkk. (2015). Sementara itu, hasil penelitian mengenai elastisitas harga silang bervariasi antar penelitian. Abdulai (2002) menemukan bahwa elastisitas harga silang pada permintaan pangan rumah tangga di Swiss cenderung kecil yang menunjukkan kemungkinan substitusi dengan barang lain relatif terbatas.

3. Variabel Demografi

Terdapat beberapa penelitian pola konsumsi pangan dengan mengikutsertakan variabel jumlah anggota rumah tangga antara lain Abdulai (2002), Tey dkk. (2009), Pangaribowo (2010), Pangaribowo dan Tsegai (2011), Abdulai dan Aubert (2004), Hayat, Hussain, dan Yousaf (2016), Bopape (2006), Faharuddin, Mulyana, dan Yunita (2015), Umam (2017), serta Arthatiani dan Kusnadi (2018). Ritonga (1994) melakukan modifikasi dengan membedakan menjadi beberapa kelompok umur. Selain jumlah anggota rumah tangga, Faharuddin, Mulyana, dan Yunita (2015) menambahkan jumlah balita sebagai variabel demografinya.

Menurut Pangaribowo dan Tsegai (2011) serta Faharuddin, Mulyana, dan Yunita (2015), variabel lama pendidikan kepala rumah tangga dianggap mencerminkan tingkat pemahaman rumah tangga dalam mengkonsumsi makanan sehat. Namun, menurut Siagian (2013) semakin lama pendidikan kepala rumah tangga belum tentu menjamin rumah tangga tersebut mengkonsumsi makanan sehat. Penelitian lain yang menggunakan variabel lama pendidikan kepala rumah tangga yaitu Umam (2017). Sementara itu, Abdulai dan Aubert (2004), Ritonga (1994) dan Arthatiani dan Kusnadi (2018) menggunakan tingkat pendidikan ibu di rumah tangga.

Selanjutnya, jenis kelamin kepala rumah tangga juga berpengaruh pada pola konsumsi pangan rumah tangga. Tey dkk. (2009) serta Faharuddin, Mulyana, dan Yunita (2015) mengemukakan hasil bahwa rumah tangga yang mempunyai kepala rumah tangga laki-laki cenderung mengkonsumsi bermacam-macam makanan. Hasil berbeda ditunjukkan oleh penelitian Pangaribowo dan Tsegai (2011). Rumah tangga yang mempunyai kepala rumah tangga perempuan cenderung mengkonsumsi makanan sehat. Peneliti lain yang menggunakan variabel jenis kelamin kepala rumah tangga yaitu penelitian dari Umam (2017).

Variabel berikutnya yaitu lapangan usaha kepala rumah tangga. Penelitian Siagian (2013), Faharuddin, Mulyana, dan Yunita (2015), Umam (2017), serta Setiana (2019) membedakan lapangan usaha kepala rumah tangga menjadi pertanian dan non pertanian. Ritonga (1994) membedakan dengan lebih detail, yaitu pekerja pertanian, wirausaha 
pertanian, wirausaha di bidang lain dan tidak bekerja (penerima pendapatan). Sementara itu, Tey dkk. (2009) membedakan lapangan usaha kepala rumah tangga dengan kategori bekerja dan tidak bekerja.

Umur merupakan salah satu variabel demografi yang diduga memengaruhi permintaan pangan. Penelitian menggunakan variabel umur dilakukan oleh Abdulai dan Aubert (2004), Tey dkk. (2009), Widarjono (2012), Arthatiani dan Kusnadi (2018).

Tipe daerah tempat tinggal dibedakan menjadi perkotaan dan perdesaan. Variabel ini dipakai oleh beberapa peneliti untuk melihat pengaruhnya terhadap permintaan pangan. Hasil penelitian Abdulai dan Aubert (2004), Tey dkk. (2009), Pangaribowo dan Tsegai (2011), Faharuddin, Mulyana, dan Yunita (2015), Sulistyaningrum (2016), Umam (2017), dan Setiana (2019) menunjukkan bahwa tipe daerah signifikan memengaruhi permintaan pangan.

Terkahir, variabel status kemiskinan rumah tangga diduga berpengaruh terhadap permintaan pangan. Menurut Tian dan Yu (2013) rumah tangga tidak miskin lebih banyak mengkonsumsi kelompok pangan yang mengandung protein dan lemak seperti ikan/udang/cumi/kerang, daging, telur dan susu dibandingkan karbohidrat seperti kelompok pangan padi-padian nonberas dan umbi.

\section{METODE RISET}

Penelitian ini menggunakan raw data hasil Survei Sosial Ekonomi Nasional (Susenas) Tahun 2018 dari Badan Pusat Statistik sebanyak 12.606 sampel. Selain Susenas, data lain yang dipakai yaitu Indeks Ketahanan Pangan tahun 2018 sebagai penentu wilayah rawan pangan Sumatera dari Badan Ketahanan Pangan Kementrian Pertanian Republik Indonesia.

Tahap awal dalam analisis pola konsumsi pangan adalah pemilihan komoditas yang diteliti. Peneliti memilih menganalisis semua komoditas yang tercantum di Susenas dengan mengeluarkan komoditas rokok dan tembakau lainnya dikarenakan pada raw data yang dipublikasikan oleh Badan Pusat Statistik, komoditas tersebut satuan standarnya berupa pilihan antara batang dan ons sehingga tidak dapat diagregasi dengan kelompok pangan rokok dan tembakau secara umum. Dalam penelitian ini, dilakukan agregasi 221 komoditas menjadi 10 komoditas pangan. Agregasi yang dilakukan berdasarkan hubungan substitusi terdekat antar komoditas yang sudah dikelompokkan di dalam kuesioner Susenas Modul Konsumsi/Pengeluaran. Agregasi dapat dilakukan berdasarkan teori yang dikemukakan oleh Lewbel (1996) yaitu generalized composite commodity yang memungkinkan pergerakan harga bersama dalam kelompok.

Penelitian ini menggunakan beberapa asumsi rumah tangga dalam pengalokasian pendapatannya (Blow, Lechene, dan Levell 2011) yaitu:

1. Konsumsi pangan dan non pangan terjadi pada kondisi yang terpisah sehingga preferensi konsumen dalam pemilihan komoditas pangan tidak tergantung pada komoditas non pangan, begitu pula sebaliknya.

2. Rumah tangga mengalokasikan pendapatannya secara dua tahap. Tahap pertama pendapatan rumah tangga dialokasikan untuk pengeluaran konsumsi pangan dan non pangan. Pada tahap kedua, rumah tangga mengalokasikan pengeluaran konsumsi pangan ke dalam komoditi-komoditi yang lebih spesifik seperti beras, daging sapi, buah dan sebagainya, yang selanjutnya diagregasi menjadi sepuluh kelompok pangan. Pada tahap kedua ini diasumsikan terdapat saling keterkaitan antara kelompok pangan tersebut sehingga pengeluaran untuk konsumsi pangan merupakan suatu sistem.

Variabel yang digunakan dalam penelitian yaitu proporsi pengeluaran (budget share) sebagai variabel dependen dengan variabel independen berupa harga pangan meliputi 10 
kelompok pangan, pendapatan rumah tangga, jumlah anggota rumah tangga, lama sekolah kepala rumah tangga, jenis kelamin kepala rumah tangga (dummy) dengan kategori perempuan dan laki-laki, lapangan usaha kepala rumah tangga (dummy) dengan kategori pertanian dan non pertanian, umur, tipe daerah (dummy) dengan kategori perdesaan dan perkotaan, serta status kemiskinann (dummy) dengan kategori rumah tangga miskin dan tidak miskin.

Pada penelitian ini digunakan analisis deskriptif dan ekonometrik. Metode analisis ekonometrik yang digunakan dalam penelitian ini menggunakan model estimasi permintaan Quadratic Almost Ideal Demand System (QUAIDS). Model QUAIDS didasarkan pada fungsi utilitas tak langsung (Banks, Blundell, dan Lewbel 1997). Variabel demografi dimasukkan pada model QUAIDS agar terdapat variasi struktur preferensi dan keheterogenan antarrumah tangga. Persamaan model QUAIDS diformulasikan mengikuti Poi (2012) sebagai berikut:

$$
\begin{aligned}
& w_{i}=\alpha_{i}+\sum_{j=1}^{n} y_{i j} \ln p_{j}+\left(\beta_{i}+\eta_{i}^{\prime} D\right) \ln \left[\frac{x}{m_{0}(D) a(p)}\right]+\left[\frac{\lambda_{i}}{b(p) c(p, D)}\right]+\left\{\ln \left[\frac{x}{m_{0}(D) a(p)}\right]\right\}^{2}+\mu_{i} \\
& \overline{m_{0}}(D)=1+\rho^{\prime} D \\
& \rho \text { adalah vektor parameter yang diestimasi (Ray, 1983) } \\
& c(p, D)=\prod_{j=1}^{n} p_{j}^{\eta_{j}^{\prime} D}
\end{aligned}
$$

keterangan:

$$
\begin{array}{ll}
i, j & : \text { kelompok pangan }(1,2,3, \ldots, 10) \\
w_{i} & \begin{array}{l}
\text { : proporsi pengeluaran (budget share) rumah tangga untuk konsumsi } \\
\text { kelompok pangan ke-i terhadap total pengeluaran konsumsi }
\end{array} \\
& \begin{array}{l}
\text { pangan } \\
: \text { harga kelompok pangan ke-j (diproksi dengan unit value yang } \\
\end{array} \\
& \text { sudah dijustifikasi) } \\
p_{j} & : \text { jumlah pengeluaran rumah tangga untuk konsumsi pangan } \\
x & : \text { vektor variabel demografi rumah tangga } \\
D & : \text { parameter } \\
\alpha_{i}, \gamma_{i j}, \beta_{i}, \lambda_{i} & : \text { vektor parameter } \\
\eta_{i}, \rho & : \text { residual } \\
u_{i} & : \text { indeks harga } \\
\ln a(p) & : \text { agregator harga Cobb Douglas } \\
b(p) &
\end{array}
$$

Menurut Poi (2012), penghitungan nilai elastisitas pengeluaran dan harga dari permintaan pangan sebagai berikut:

1. Elastisitas Pengeluaran

$$
\begin{gathered}
e_{i}=1+\frac{\mu_{i}}{w_{i}} \\
\mu_{i}=\frac{\partial w_{i}}{\partial \ln x}=\left(\beta_{i}+\eta_{i}^{\prime} D\right)+\frac{2 \lambda_{i}}{b(p) c(p, D)} \ln \left[\frac{x}{\overline{m_{0}(D) a(p)}}\right]
\end{gathered}
$$

2. Elastisitas Harga Marshallian

$$
\begin{gathered}
e_{i j}^{u}=\frac{\mu_{i j}}{w_{i}}-\delta_{i j} \\
\mu_{i j}=\frac{\partial w_{i}}{\partial \ln p_{j}}=\gamma_{i j}-\mu_{i}\left(a_{j}+\sum_{k} \gamma_{j k} \ln p_{k}\right)-\frac{\lambda_{i}\left(\beta_{i}+\eta_{i}^{\prime} D\right)}{b(p) c(p, D)}\left\{\ln \left[\frac{x}{a(p)}\right]\right\}^{2}
\end{gathered}
$$

3. Elastisitas Harga Hicksian

$$
e_{i j}^{c}=e_{i j}^{u}+w_{j} e_{i}
$$


Pada perhitungan model QUAIDS, elastisitas pengeluaran yang dihasilkan adalah elastisitas terhadap pengeluaran pangan, bukan terhadap total pengeluaran rumah tangga (pangan dan non pangan). Untuk menghasilkan elastisitas pengeluaran total, perlu dilakukan perkalian antara elastisitas pengeluaran pada model QUAIDS dengan elastisitas total pengeluaran pangan terhadap total pengeluaran rumah tangga. Nilai elastisitas total pengeluaran pangan terhadap total pengeluaran rumah tangga diestimasi dengan model kuadratik fungsi pendapatan Engel (Chern 2000 dalam Tey dkk. 2009) sebagai berikut:

keterangan:

$$
\ln x_{i}=\alpha_{0}+\alpha_{1} \ln X_{i}+\alpha_{2}\left(\ln X_{i}\right)^{2}+\sum_{k} \gamma_{k} D_{k}+\varepsilon_{i}
$$

$\begin{array}{ll}x_{i} & : \text { total pengeluaran konsumsi pangan rumah tangga ke-i } \\ X_{i} & : \text { total pengeluaran konsumsi rumah tangga ke-i } \\ D_{k} & : \text { variabel demografi yang dipakai dalam model QUAIDS } \\ \alpha_{1}, \alpha_{2}, \gamma_{k} & : \text { parameter } \\ \varepsilon_{i} & : \text { residual }\end{array}$

Elastisitas pengeluaran pangan terhadap total pengeluaran diperoleh dari perhitungan:

$$
e_{y}=\alpha_{1}+2 \alpha_{2} \ln X_{i}
$$

Selanjutnya, nilai elastisitas pendapatan atau elastisitas pengeluaran kelompok pangan terhadap total pengeluaran rumah tangga $\left(\eta_{i}\right)$ dihitung dengan formula

$$
\eta_{i}=e_{i} x e_{y}
$$

Variabel harga dalam penelitian ini menggunakan pendekatan unit value yaitu rasio antara pengeluaran pangan terhadap kuantitas pangan yang dikonsumsi yang dihitung dari data Susenas. Pendekatan unit value mengacu pada Deaton $(1987,1990)$ serta Gibson dan Kim (2019). Karena menggunakan kelompok pangan, maka penghitungan harga melibatkan rata-rata tertimbang. Nilai per satuan (unit value) kelompok pangan ke-i $\left(\eta_{i}\right)$ dirumuskan sebagai berikut:

keterangan:

$$
\begin{array}{r}
v_{i}=\sum_{j}\left[v_{i j} \frac{x_{i j}}{x_{i}}\right] \\
v_{i j}=\frac{x_{i j}}{q_{i j}}
\end{array}
$$

$i$
$x_{i j}$
$q_{i j}$
$x_{i}$
$v_{i j}$

: kelompok pangan ke-i $(1,2,3, \ldots, 10)$

: komoditas pangan ke-j $(1,2,3, \ldots, 221)$

: pengeluaran rumah tangga untuk komoditas pangan ke-j kelompok pangan ke-i

: kuantitas konsumsi pangan rumah tangga untuk komoditas pangan ke-j kelompok pangan ke-i

: pengeluaran rumah tangga untuk kelompok pangan ke-i

: harga yang dibayarkan rumah tangga untuk komoditas pangan

ke-j kelompok pangan ke-i

Permasalahan dari penggunaan variabel harga adalah konsumen yang berbeda biasanya mendapatkan harga yang berbeda dengan komoditas yang sama. Hal ini disebabkan terdapat perbedaan dalam jumlah pembelian (quantity premium) maupun kualitas (quality effect). Padahal berdasarkan teori, setiap konsumen dalam suatu komunitas seharusnya menghadapi harga pasar yang sama. Oleh karena itu, unit value biasanya dijustifikasi terlebih dahulu sebelum digunakan dalam model estimasi. Justifikasi unit value mengacu pada 
penelitian Cox dan Wohlgenant (1986) yang dilakukan penyesuaian seperti studi Vu (2009) sebagai berikut.

keterangan:

$$
\begin{gathered}
v_{i}=\bar{v}_{l}+\varphi_{i} x+\theta D+\varepsilon_{i} \\
p_{i}=\bar{v}_{l}+\hat{\varepsilon}_{l}
\end{gathered}
$$

$v_{i} \quad$ : unit value kelompok pangan ke-i $(1,2,3, \ldots, 10)$

$\overline{v_{l}} \quad$ : rata-rata unit value

$x \quad$ : total pengeluaran pangan rumah tangga

$D \quad$ : vektor variabel demografi

$\varphi_{i} \quad$ : parameter

$\theta \quad$ : vektor parameter

$\varepsilon_{i} \quad$ : residual

$p_{i} \quad$ : rata-rata unit value kelompok komoditas pangan ke-i hasil koreksi pada tingkat komunitas kabupaten/kota (nilai ini yang digunakan sebagai variabel harga dalam model QUAIDS).

Dampak perubahan harga terhadap kesejahteraan rumah tangga dapat diukur menggunakan fungsi utilitas tidak langsung money metric. Dengan referensi satu set harga, dapat dihitung seberapa baik atau buruk tingkat utilitas rumah tangga diukur dari pergerakan tingkat ulititas menuju tingkat utilitas baru dalam menanggapi perubahan harga.

Sesuai dengan penelitian sebelumnya (Weber, 2015), dampak kesejahteraan dari perubahan harga makanan berupa compensating variation (CV) yang merupakan jumlah uang dibutuhkan rumah tangga pada tingkat harga baru untuk mencapai tingkat utilitas awal. Fungsi pengeluaran dapat ditunjukkan oleh persamaan berikut

$$
C V=c\left(P_{1}, u_{0}\right)-c\left(P_{0}, u_{0}\right)
$$

Angka 0 menunjukkan kondisi sebelum perubahan harga dan 1 menunjukkan kondisi sesudah perubahan harga. CV dapat dihitung dengan menggunakan pengembangan pendekatan first order Taylor expansion dari fungsi pengeluaran minimum sebagai (Friedman \& Levinsohn, 2002):

$$
\ln C^{h} \approx \sum_{i=1}^{n} w_{i}^{h} \Delta \ln P_{i}^{h}+\frac{1}{2} \sum_{i=1}^{n} \sum_{i=j}^{n} w_{i}^{h} \varepsilon_{i j} \Delta \ln P_{i}^{h} \Delta \ln P_{j}^{h}
$$

i menunjukkan kelompok pangan di dalam sistem dan $\mathrm{h}$ menunjukkan rumah tangga. $\boldsymbol{w}_{\boldsymbol{i}}^{\boldsymbol{h}}$ merupakan proporsi anggaran untuk kelompok pangan i pada anggaran pangan rumah tangga yang diperoleh dengan membagi pengeluaran awal (sebelum perubahan harga) komoditas i terhadap total pengeluaran pangan. Bagian pertama persamaan 17 hanya menghitung dampak maksimum akibat adanya perubahan harga dan mengabaikan respon perilaku individu dan efek substitusi terhadap komoditas yang harganya relatif lebih murah. Karena itu, digunakan pendekatan second order Taylor expansion pada persamaan 17 tersebut dengan menambahkan bagian kedua yang mempertimbangkan elastisitas harga sendiri dan harga silang untuk menangkap respon perilaku rumah tangga.

\section{ANALISIS DATA DAN PEMBAHASAN}

Pengeluaran rumah tangga merupakan salah satu indikator gambaran keadaan kesejahteraan rumah tangga. Tabel 1 menyajikan gambaran umum rata-rata pengeluaran pangan dan proporsi pengeluaran pagan rumah tangga di wilayah rawan pangan Sumatera. Pengeluaran untuk pangan merupakan pengeluaran yang mendominasi total pengeluaran rumah tangga. Hal ini sesuai dengan penelitian Mauludyani, Martianto, dan Baliwati (2008). 
Apabila dibedakan menurut beberapa klasifikasi yang tertulis pada kolom 1, rumah tangga yang tinggal di wilayah perkotaan merupakan rumah tangga yang paling kecil proporsi pengeluaran pangan terhadap total pengeluarannya sedangkan rumah tangga miskin merupakan rumah tangga yang paling besar proporsi pengeluaran pangannya.

Tabel 1

Rata-Rata Pengeluaran Pangan Dan Proporsi Pengeluaran Pangan Menurut Karakteristik Rumah Tangga Di Wilayah Rawan Pangan Sumatera Tahun 2018

\begin{tabular}{lcc}
\hline \multicolumn{1}{c}{ Karakteristik } & $\begin{array}{c}\text { Pengeluaran Pangan } \\
\text { (Rp/Kap/Bulan) }\end{array}$ & $\begin{array}{c}\text { Proporsi Pengeluaran } \\
\text { Pangan (Persen) }\end{array}$ \\
\hline KRT Perempuan & $(2)$ & $(3)$ \\
\hline KRT Laki-Laki & 626882,65 & 49,11 \\
\hline KRT Pertanian & 626229,61 & 52,53 \\
\hline KRT Non Pertanian & 569442,83 & 55,79 \\
\hline Miskin & 687990,03 & 49,08 \\
\hline Tidak Miskin & 267957,09 & 62,70 \\
\hline Kota & 663050,91 & 51,68 \\
\hline Desa & 689160,93 & 48,71 \\
\hline Rawan Pangan & 582122,30 & 55,18 \\
Sumatera & 626318,41 & 52,04 \\
\hline Sumber: Susenas & &
\end{tabular}

Sumber: Susenas Maret 2018 Badan Pusat Statistik (diolah)

Tabel 2 menunjukkan proporsi rata-rata pengeluaran kelompok pangan rumah tangga yang diurutkan dari kuintil pengeluaran 1 sampai dengan 5 dengan klasifiksai perkotaan dan perdesaan. Kuintil 1 merupakan rumah tangga dengan kelompok pengeluaran 20 persen terbawah sedangkan kuintil 5 merupakan rumah tangga dengan kelompok pengeluaran 20 persen teratas dari seluruh rumah tangga di wilayah rawan pangan Sumatera.

Tabel 2

Proporsi Rata-Rata Pengeluaran Kelompok Pangan Rumah Tangga Menurut Kuintil Pengeluaran Perkotaan Dan Perdesaan di Wilayah Rawan Pangan Sumatera Tahun 2018

\begin{tabular}{|c|c|c|c|c|c|}
\hline \multirow{2}{*}{ Kelompok Pangan } & \multicolumn{5}{|c|}{ Kuintil } \\
\hline & 1 & 2 & 3 & 4 & 5 \\
\hline (1) & $(2)$ & (3) & $(4)$ & (5) & (6) \\
\hline Beras & 22,12 & 17,89 & 14,89 & 12,45 & 9,55 \\
\hline $\begin{array}{l}\text { Padi-Padian Nonberas dan } \\
\text { Umbi }\end{array}$ & 1,81 & 1,61 & 1,57 & 1,54 & 1,41 \\
\hline Ikan/Udang/Cumi/Kerang & 12,21 & 11,59 & 11,80 & 12,12 & 12,47 \\
\hline Daging & 2,52 & 3,28 & 3,85 & 4,28 & 5,10 \\
\hline Telur dan Susu & 4,47 & 4,93 & 5,38 & 5,77 & 7,02 \\
\hline $\begin{array}{l}\text { Sayur, Buah, dan Kacang- } \\
\text { Kacangan }\end{array}$ & 15,71 & 14,93 & 14,68 & 14,31 & 13,99 \\
\hline Minyak dan Kelapa & 4,38 & 3,65 & 3,31 & 2,94 & 2,40 \\
\hline Makanan Jadi & 18,66 & 21,57 & 23,77 & 25,63 & 29,62 \\
\hline Konsumsi Lainnya & 9,98 & 8,74 & 8,03 & 7,37 & 6,45 \\
\hline Rokok dan Tembakau & 8,15 & 11,81 & 12,72 & 13,57 & 11,98 \\
\hline Pangan & 100 & 100 & 100 & 100 & 100 \\
\hline
\end{tabular}

Sumber: Susenas Maret 2018 Badan Pusat Statistik (diolah) 
Terdapat perbedaan pola konsumsi pangan antar kuintil rumah tangga. Beras merupakan kelompok pangan yang paling banyak dikonsumsi pada rumah tangga kuintil 1 dengan besaran 22,12 persen dari keseluruhan kelompok pangan dan semakin menurun presntasenya untuk kuintil 2 sampai 5 . Sedangkan makanan jadi merupakan kelompok pangan yang paling banyak dikonsumsi rumah tangga pada kuintil 2 sampai 5.

Karakteristik sampel rumah tangga di wilayah rawan pangan Sumatera ditunjukkan oleh tabel 3.

Tabel 3

Karakteristik Rumah Tangga di Wilayah Rawan Pangan Sumatera

\begin{tabular}{|c|c|c|c|}
\hline No. & Variabel & Kategori & $\begin{array}{c}\text { Presentase Rumah } \\
\text { Tangga }\end{array}$ \\
\hline (1) & (2) & (3) & (4) \\
\hline \multirow{3}{*}{1} & \multirow{3}{*}{$\begin{array}{l}\text { Jenis Kelamin } \\
\text { Kepala Rumah } \\
\text { Tangga }\end{array}$} & Perempuan & 13,60 \\
\hline & & Laki-Laki & 86,40 \\
\hline & & Total & 100,00 \\
\hline \multirow{3}{*}{2} & \multirow{3}{*}{$\begin{array}{l}\text { Lapangan Usaha } \\
\text { Kepala Rumah } \\
\text { Tangga }\end{array}$} & Pertanian & 52,02 \\
\hline & & Non Pertanian & 47,98 \\
\hline & & Total & 100,00 \\
\hline \multirow{3}{*}{3} & \multirow{3}{*}{ Tipe Daerah } & Perkotaan & 41,29 \\
\hline & & Perdesaan & 58,71 \\
\hline & & Total & 100,00 \\
\hline \multirow{3}{*}{4} & \multirow{3}{*}{ Status Kemiskinan } & RT Miskin & 9.30 \\
\hline & & RT Tidak Miskin & 90,70 \\
\hline & & Total & 100,00 \\
\hline
\end{tabular}

Sumber: Susenas Maret 2018 Badan Pusat Statistik (diolah)

Terlihat bahwa jenis kelamin kepala rumah tangga di wilayah rawan pangan sebagian besar laki-laki sebanyak 86,40 persen, hanya sebagian kecil perempuan sebesar 13,60 persen. Hal ini sejalan dengan karakteristik rumah tangga di Indonesia yang masyarakatnya cenderung mempunyai kepala rumah tangga laki-laki karena dianggap lebih baik dalam memimpin daripada perempuan (Hurlock 2004; Crawford dan Unger 2004).

Selanjutnya, lapangan usaha utama kepala rumah tangga lebih banyak yang bekerja di bidang pertanian yaitu sebanyak 52,02 persen daripada non pertanian sebanyak 47,98 persen. Dari 52,02 persen tersebut, subsektor yang paling banyak menjadi lapangan usaha kepala rumah tangga yaitu subsektor perkebunan, diikuti perikanan, pertanian padi dan palawija, hortikultura, kehutanan dan pertanian lainnya, serta peternakan. 


\section{Lapangan Usaha Utama Rumah Tangga di Wilayah Rawan Pangan Sumatera Subsektor Pertanian (Persen) Tahun 2018}

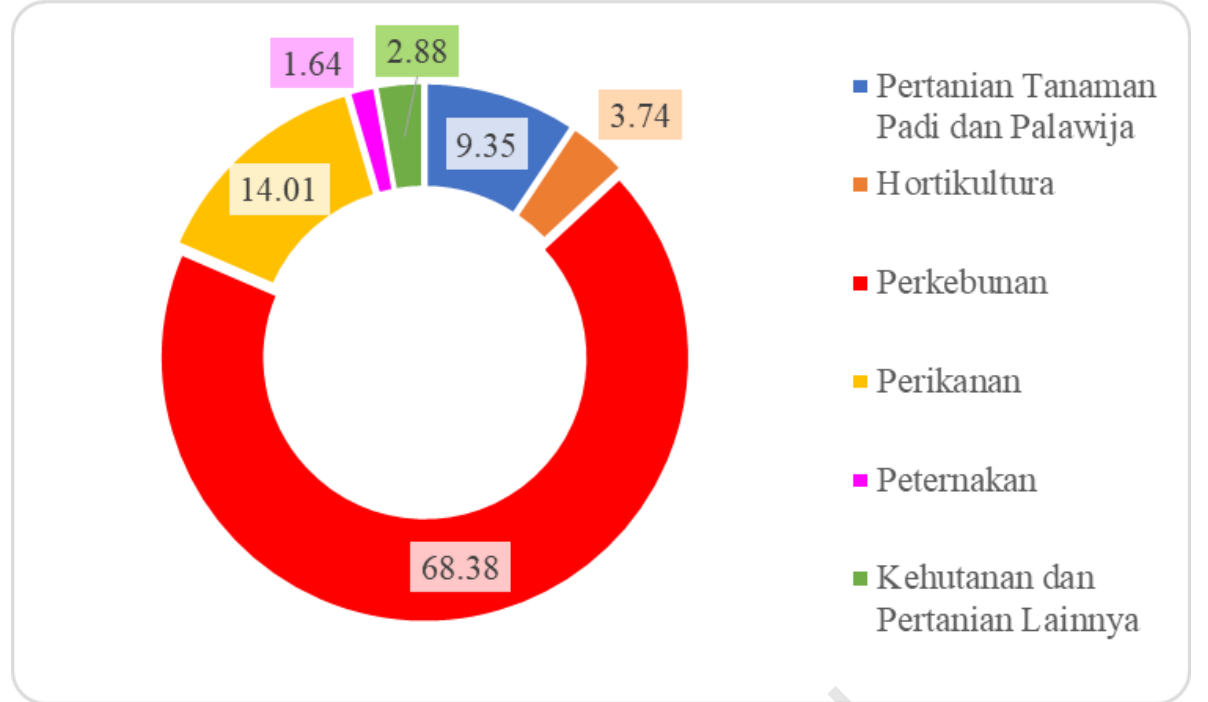

Sumber: Susenas Maret 2018 Badan Pusat Statistik (diolah)

Tipe daerah wilayah rawan pangan Sumatera lebih banyak di wilayah perdesaan dibandingkan perkotaan. Dapat dilihat bahwa perdesaan sebesar 58,71 persen sedangkan perkotaan hanya 41,29 persen. Selanjutnya, rumah tangga di wilayah rawan pangan sebagian besar bukan merupakan rumah tangga miskin sebesar 90,70 persen sedangkan jumlah rumah tangga miskin sebesar 9,30 persen.

Salah satu hasil estimasi model QUAIDS adalah nilai elastisitas permintaan yang merupakan indikator untuk melihat respon konsumen terhadap permintaan kelompok pangan karena perubahan pendapatan, harga sendiri, dan harga komoditas lain.

Nilai elastisitas pendapatan yang didekati dengan pengeluaran $(\mathrm{Vu}, 2020)$ dalam penelitian ini diperoleh dari perkalian nilai elastisitas permintaan pangan dari model kuadrat pendapatan Engel dengan elastisitas permintaan kelompok pangan terhadap pengeluaran pangan dari model QUAIDS. Hasil dari estimasi pendapatan dapat dipakai untuk melihat sifat suatu komoditas termasuk barang normal (pokok), mewah, atau inferior. Nilai elastisitas pendapatan dalam penelitian ini menggunakan nilai median sesuai penelitian Poi (2012). Nilai elastisitas pendapatan disajikan pada Tabel 4.

Elastisitas pendapatan semua kelompok pangan rumah tangga di wilayah rawan pangan Sumatera bernilai positif, baik secara total maupun menurut tipe daerah. Nilai positif elastisitas menunjukkan bahwa meningkatnya pendapatan akan meningkatkan permintaan terhadap suatu kelompok pangan. Hasil ini sesuai dengan penelitian Ritonga (1994), Abdulai (2002), Abdulai dan Aubert (2004), Pangaribowo dan Tsegai (2011), Wang (2014), Ulubasoglu dkk. (2015), Hoang (2018), serta Setiana (2019).

Apabila nilai elastisitas pendapatan bernilai lebih dari 0 dan kurang dari 1 menunjukkan bahwa kelompok pangan tersebut merupakan barang normal, sedangkan jika bernilai lebih dari 1 menunjukkan bahwa kelompok barang tersebut merupakan barang mewah (Bochańczyk-Kupka 2019, 259-260). Secara umum, sebagian besar kelompok pangan merupakan barang normal untuk rumah tangga di wilayah rawan Sumatera pangan kecuali daging, makanan jadi serta rokok dan tembakau. Hal ini sesuai dengan hasil penelitian Setiana (2019). 
Tabel 4

Elastisitas Pendapatan Kelompok Pangan

di Wilayah Rawan Pangan Sumatera

\begin{tabular}{lc}
\hline \multicolumn{1}{c}{ Kelompok Pangan } & Total \\
\hline \multicolumn{1}{c}{$(1)$} & $(2)$ \\
\hline Beras & 0,16 \\
\hline Padi-Padian Nonberas dan Umbi & 0,83 \\
\hline Ikan/Udang/Cumi/Kerang & 0,84 \\
\hline Daging & 1,06 \\
\hline Telur dan Susu & 0,94 \\
\hline Sayur, Buah, dan Kacang-Kacangan & 0,72 \\
\hline Minyak dan Kelapa & 0,42 \\
\hline Makanan Jadi & 1,15 \\
\hline Konsumsi Lainnya & 0,42 \\
\hline Rokok dan Tembakau & 1,10 \\
\hline Sumber: Hasil pengolahan STATA
\end{tabular}

Sumber: Hasil pengolahan STATA

Kelompok makanan jadi merupakan komoditas yang memliki nilai elastisitas paling tinggi pada semua kelompok pangan rumah tangga dengan nilai 1,15 . Hal ini menunjukkan bahwa rumah tangga di wilayah rawan pangan akan meningkatkan konsumsi makanan jadi ketika pendaptannya meningkat. Terlihat pada tabel 4 , tidak terdapat barang inferior pada seluruh kelompok pangan.

Pada penelitian ini, elastisitas harga sendiri dan dengan komoditas lain (silang) dihitung secara terkompensasi (compensated elasticities/hicksian). Elastisitas harga hicksian lebih baik apabila dipakai untuk dasar pembuatan kebijakan karena sudah memperhitungkan efek kesejahteraan bagi konsumen (Fashogbon dan Oni 2013).

Nilai elastisitas harga sendiri seluruh kelompok pangan pada semua rumah tangga di wilayah rawan pangan Sumatera bernilai negatif. Nilai negatif pada elastisitas harga sendiri menujukkan bahwa peningkatan harga suatu kelompok pangan mengurangi permintaan pangan kelompok pangan tersebut. Sebelum menginterpretasikan hasil elastisitas tersebut, nilainya harus dimutlakkan terlebih dahulu atau berupa ukuran absolut (Pindyck dan Rubinfeld 2018, 55).

Tabel 5 menunjukkan kelompok pangan yang paling responsif terhadap perubahan harga sendiri adalah padi-padian nonberas dan umbi dengan nilai |-3,40| persen. Arti dari nilai tersebut yaitu kenaikan harga padi-padian nonberas dan umbi sebesar 10 persen akan menurunkan konsumsi sebesar 34 persen dan kelompok pangan ini bersifat elastis. Hal ini menandakan bahwa permintaan kelompok padi-padian nonberas dan umbi bersifat sensitif terhadap perubahan harga terutama di perdesaan. Nilai elastisitas beras lebih inelastis dibandingkan padi-padian nonberas dan umbi. Hal ini menunjukkan beras masih menjadi makanan pokok rumah tangga di wilayah rawan pangan karena permintaannya lebih tidak sensitif terhadap perubahan harga dibandingkan padi-padian nonberas dan umbi. Hal ini sesuai dengan hasil penelitian Siagian (2013) dan Setiana (2019). Walaupun terdapat perubahan harga beras, permintaan komoditas beras tidak mengalami banyak perubahan karena setiap orang berusaha mempertahankan kuantitas beras yang dikonsumsi (Sugiyanto, 2006). 
Tabel 5

Elastisitas Harga Sendiri Permintaan Pangan Rumah Tangga di Wilayah Rawan Pangan Sumatera

\begin{tabular}{lccc}
\hline \multicolumn{1}{c}{ Kelompok Pangan } & Total & Desa & Kota \\
\hline \multicolumn{1}{c}{$(1)$} & $(2)$ & $(3)$ & $(4)$ \\
\hline Beras & $|-2,35|$ & $|-2,80|$ & $|-2,14|$ \\
\hline Padi-Padian Nonberas dan Umbi & $|-3,40|$ & $|-3,85|$ & $|-3,16|$ \\
\hline Ikan/Udang/Cumi/Kerang & $|-1,16|$ & $|-1,14|$ & $|-1,17|$ \\
\hline Daging & $|-2,57|$ & $|-2,50|$ & $|-2,62|$ \\
\hline Telur dan Susu & $|-0,98|$ & $|-0,96|$ & $|-1,25|$ \\
\hline Sayur, Buah, dan Kacang- & & & \\
Kacangan & $|-1,22|$ & $|-1,23|$ & $|-1,22|$ \\
\hline Minyak dan Kelapa & $|-2,91|$ & $|-3,18|$ & $|-2,76|$ \\
\hline Makanan Jadi & $|-1,11|$ & $|-1,12|$ & $|-1,10|$ \\
\hline Konsumsi Lainnya & $|-1,06|$ & $|-0,95|$ & $|-1,15|$ \\
\hline Rokok dan Tembakau & $|-0,42|$ & $|-0,36|$ & $|-0,45|$ \\
\hline Sumber: Hasil Pengolahan STATA & & &
\end{tabular}

Elastisitas harga silang menunjukkan hubungan perubahan harga suatu komoditas terhadap permintaan komoditas lain. Nilai elastisitas harga silang dapat bertanda negatif atau positif. Nilai negatif menunjukkan hubungan komplementer/pelengkap, sedangkan nilai positif menunjukkan hubungan substitusi/pengganti (Nicholson 2005, 179).

Padi-padian nonberas dan umbi merupakan salah satu kelompok pangan yang menjadi substitusi dari beras. Kedua kelompok pangan tersebut mengandung karbohidrat sehingga dapat saling menggantikan.

Tabel 6 Elastisitas Harga Silang Permintaan Pangan Rumah Tangga Di Wilayah Rawan Pangan Sumatera

\begin{tabular}{|c|c|c|c|c|c|c|c|c|c|c|}
\hline $\begin{array}{c}\text { Kelompok } \\
\text { Pangan }\end{array}$ & Beras & $\begin{array}{l}\text { Padi- } \\
\text { Padian } \\
\text { Nonbe } \\
\text { ras dan } \\
\text { Umbi }\end{array}$ & $\begin{array}{c}\text { Ikan/ } \\
\text { Udang/ } \\
\text { Cumi/ } \\
\text { Kerang }\end{array}$ & Daging & $\begin{array}{l}\text { Telur } \\
\text { dan } \\
\text { Susu }\end{array}$ & $\begin{array}{c}\text { Sayur, } \\
\text { Buah, dan } \\
\text { Kacang- } \\
\text { Kacangan }\end{array}$ & $\begin{array}{c}\text { Minyak } \\
\text { dan } \\
\text { Kelapa }\end{array}$ & $\begin{array}{l}\text { Makanan } \\
\text { Jadi }\end{array}$ & $\begin{array}{l}\text { Konsumsi } \\
\text { Lainnya }\end{array}$ & $\begin{array}{l}\text { Rokok dan } \\
\text { Tembakau }\end{array}$ \\
\hline (1) & (2) & (3) & (4) & (5) & (6) & (7) & (8) & (9) & (10) & (11) \\
\hline Beras & $-2,35$ & 0,24 & $-0,11$ & 0,20 & 0,45 & 0,32 & 0,20 & 0,22 & 0,29 & 0,55 \\
\hline Padi-Padian & & & & & & & & & & \\
\hline $\begin{array}{l}\text { Nonberas dan } \\
\text { Umbi }\end{array}$ & 2,35 & $-3,40$ & 0,35 & $-0,62$ & $-0,63$ & 0,97 & 0,35 & 0,71 & 0,54 & $-0,62$ \\
\hline $\begin{array}{l}\text { Ikan/Udang/ } \\
\text { Cumi/Kerang }\end{array}$ & $-0,15$ & 0,05 & $-1,16$ & 0,04 & 0,08 & 0,37 & 0,10 & $-0,10$ & 0,74 & 0,04 \\
\hline Daging & 0,80 & $-0,26$ & 0,12 & $-2,57$ & 0,84 & 0,37 & 0,12 & 0,33 & 0,18 & 0,06 \\
\hline $\begin{array}{l}\text { Telur dan } \\
\text { Susu }\end{array}$ & 1,26 & $-0,18$ & 0,18 & 0,58 & $-0,98$ & $-0,23$ & $-0,04$ & $-0,18$ & 0,31 & $-0,71$ \\
\hline
\end{tabular}




\begin{tabular}{|c|c|c|c|c|c|c|c|c|c|c|}
\hline $\begin{array}{c}\text { Kelompok } \\
\text { Pangan }\end{array}$ & Beras & $\begin{array}{l}\text { Padi- } \\
\text { Padian } \\
\text { Nonbe } \\
\text { ras dan } \\
\text { Umbi }\end{array}$ & $\begin{array}{c}\text { Ikan/ } \\
\text { Udang/ } \\
\text { Cumi/ } \\
\text { Kerang }\end{array}$ & Daging & $\begin{array}{l}\text { Telur } \\
\text { dan } \\
\text { Susu }\end{array}$ & $\begin{array}{c}\text { Sayur, } \\
\text { Buah, dan } \\
\text { Kacang- } \\
\text { Kacangan }\end{array}$ & $\begin{array}{l}\text { Minyak } \\
\text { dan } \\
\text { Kelapa }\end{array}$ & $\begin{array}{c}\text { Makanan } \\
\text { Jadi }\end{array}$ & $\begin{array}{l}\text { Konsumsi } \\
\text { Lainnya }\end{array}$ & $\begin{array}{l}\text { Rokok dan } \\
\text { Tembakau }\end{array}$ \\
\hline (1) & (2) & (3) & (4) & (5) & (6) & (7) & (8) & (9) & (10) & (11) \\
\hline $\begin{array}{l}\text { Sayur, Buah, } \\
\text { dan Kacang- } \\
\text { Kacangan }\end{array}$ & 0,33 & 0,10 & 0,30 & 0,10 & $-0,09$ & $-1,22$ & 0,03 & 0,15 & 0,31 & $-0,02$ \\
\hline $\begin{array}{l}\text { Minyak dan } \\
\text { Kelapa }\end{array}$ & 0,91 & 0,17 & 0,36 & 0,14 & $-0,07$ & 0,15 & $-2,91$ & 0,46 & 0,37 & 0,44 \\
\hline Makanan Jadi & 0,42 & 0,14 & $-0,15$ & 0,16 & $-0,13$ & 0,27 & 0,19 & $-1,11$ & 0,31 & $-0,10$ \\
\hline $\begin{array}{l}\text { Konsumsi } \\
\text { Lainnya }\end{array}$ & 0,19 & 0,04 & 0,37 & 0,03 & 0,07 & 0,19 & 0,05 & 0,11 & $-1,06$ & 0,01 \\
\hline $\begin{array}{l}\text { Rokok dan } \\
\text { Tembakau }\end{array}$ & 0,72 & $-0,08$ & 0,04 & 0,02 & $-0,34$ & $-0,02$ & 0,13 & $-0,07$ & 0,02 & $-0,42$ \\
\hline
\end{tabular}

Sumber: Hasil Pengolahan STATA

Jika dibandingkan, kenaikan harga padi-padian nonberas dan umbi lebih banyak menyebabkan pengurangan konsumsi kelompok pangan lain daripada padi-padian nonberas. Hal ini membuktikan bahwa beras yang dijual secara langusng tidak lagi menjadi bahan pangan pokok di wilayah rawan pangan Sumatera. Diduga hal ini karena masyarakat lebih memilih mengkonsumsi beras dalam bentuk makanan jadi.

Apabila dibandingkan antar kelompok pangan yang cukup banyak mengandung protein yaitu ikan, udang, cumi, kerang; daging; serta telur dan susu, terlihat bahwa jika terjadi kenaikan harga ketiga kelompok pangan tersebut, telur dan susu menjadi kelompok pangan yang menyebabkan paling banyak pengurangan terhadap konsumsi kelompok pangan lain. Hal ini menunjukkan telur dan susu merupakan kelompok pangan protein yang menjadi pilihan utama sebagian besar rumah tangga rawan pangan Sumatera. Jenis kelompok pangan yang mengalami pengurangan cukup beraneka ragam. Hal ini berakibat pada berkurangnya asupan nutrisi rumah tangga.

Estimasi perubahan kesejahteraan rumah tangga akibat adanya kenaikan harga pangan dapat dihitung melalui compensating variation (CV). CV merupakan total transfer yang dibutuhkan oleh rumah tangga ketika terjadi kenaikan harga untuk dapat mencapai titik utilitas awal atau sebelum terjadi kenaikan harga. Penelitian ini mensimulasikan dampak kesejahteraan rumah tangga akibat adanya kenaikan harga pangan sebesar 10 persen, 25 persen dan 50 persen. Nilai CV pada tabel 7 menunjukkan hasil perhitungan CV berdasarkan elastisitas Hicksian yang juga telah digunakan oleh peneliti sebelumnya (Weber, 2015). 
Tabel 7

Presentase Perubahan Kesejahteraan Berdasarkan Compensating Variation Menurut Karakteristik Rumah Tangga di Wilayah Rawan Pangan Sumatera

\begin{tabular}{cc}
\hline $\begin{array}{c}\text { Presentase } \\
\text { Kenaikan Harga } \\
\text { Pangan (Persen) }\end{array}$ & $\begin{array}{c}\text { Perubahan Kesejahteraan Kelompok Rumah } \\
\text { Tangga Rawan Pangan di Sumatera (Persen) }\end{array}$ \\
\hline$(1)$ & $(2)$ \\
\hline 10 & 9,53 \\
\hline 25 & 22,32 \\
\hline 50 & 40,56 \\
\hline
\end{tabular}

Sumber: Hasil Pengolahan

Apabila pengitungan CV menghasilkan nilai positif maka terdapat penurunan tingkat kesejahteraan (welfare loss) dan sebaliknya. Pada tabel 7 terlihat bahwa semakin tinggi kenaikan harga pangan maka semakin banyak pula pengurangan kesejahteraan. Namun, perbandingan kenaikan harga pagan dan penurunan kesejahteraan semakin mengecil ketika kenaikan harga semakin tinggi. Simulasi menunjukkan apabila harga pangan naik 10 persen akan menurunkan kesejahteraan rumah tangga di wilayah rawan pangan di Sumatera sebesar 9,53 persen. Jika harga pangan mengalami peningkatan 25 persen akan menurunkan kesejahteraan rumah tangga sebesar 22,32 persen dan apabila peningkatan harga pangannya sebesar 50 persen maka kesejahteraan rumah tangga berkurang sebesar 40,56 persen.

\section{SIMPULAN, KETERBATASAN, SARAN, DAN REKOMENDASI}

Berdasarkan hasil analisis dan pembahasan dapat disimpulkan bahwa semakin tinggi kenaikan harga pangan maka semakin banyak pula pengurangan kesejahteraan rumah tangga. Konsumsi pangan rumah tangga di wilayah rawan pangan Sumatera masih mendominasi pengeluaran rumah tangga. Proporsi pengeluaran kelompok pangan rumah tangga didominasi oleh kelompok pangan untuk rumah tangga berpendapatan rendah dan makanan jadi untuk rumah tangga berpendapatan tinggi.

Elastisitas pendapatan semua kelompok pangan bernilai positif. Sementara itu, nilai elastisitas harga sendiri seluruh kelompok pangan bernilai negatif dan untuk menginterpretasikannya dimutlakkan sehingga bernilai positif. Nilai elastisitas harga silang bervariasi antar kelompok pangan. Variabel-variabel demografi berpengaruh terhadap pola konsumsi pangan kecuali jenis kelamin kepala rumah tangga dan status kemiskinan rumah tangga. Pengaruh variabel demografi tersebut bervariasi pada setiap kelompok pangan.

Saran kebijakan untuk pemerintah yaitu dengan peningkatan pendapatan masyarakat dan menjaga kestabilan harga atau menurunkan harga pangan. Penelitian ini masih mengandung keterbatasan yaitu data pendapatan rumah tanga tidak dapat diperoleh sehingga menggunakan pendekatan pengeluaran rumah tangga. Penelitian ini menggunakan data susenas 2018 karena data susenas terbaru tahun 2019 yang sudah dilaksanakan kegiatannya belum tersedia raw datanya hingga penelitian ini dilakukan. Harga kelompok pangan yang digunakan bukan berasal dari harga riil pasar. Sampai sekarang, belum terdapat data harga pasar yang sesuai dengan kelompok pangan dalam penelitian ini. Oleh karena itu, untuk penelitian selanjutnya disarankan menggunakan data Susenas terbaru tahun 2019 dan variabel data harga pasar jika sudah tersedia. Lebih lanjut penelitian ini dapat dikembangkan menjadi analisis pola konsumsi rumah tangga di wilayah rawan pangan dan tahan pangan. 


\section{DAFTAR PUSTAKA}

Abdulai, A. (2002). Household Demand for Food in Switzerland. A Quadratic Almost Ideal Demand System. Schweizerische Zeitschrift für Volkswirtschaft und Statistik / Revue Suisse d'Economie Politique et de Statistique, 138, 1-18. Diakses pada 27 Juli 2020. Diambil dari http://www.sjes.ch/papers/2002-l-1.pdf

Abdulai, A., \& Aubert, D. (2004). A Cross-Section Analysis of Household Demand for Food and Nutrients in Tanzania. Agricultural Economics, 31(1), 67-79. Diakses pada 15 Juli 2020. https://doi.org/10.1016/j.agecon.2003.03.001

Arthatiani, F. Y., \& Kusnadi, N. (2018). Analisis Pola Konsumsi dan Model Permintaan Ikan Menurut Karakteristik Rumah Tangga di Indonesia. jurnal sosek $K P, 13(021), 73-86$. Diakses pada 15 Juli 2020. Diambil dari http://ejournalbalitbang.kkp.go.id/index.php/sosek/article/view/6967/5863

Badan Ketahanan Pangan Kementrian Pertanian. (2018). Rencana Strategis Badan Ketahanan Pangan Tahun 2015-2019 Revisi ke-3. Diambil dari http://bkp.pertanian.go.id/storage/app/media/Evalap/renstra-bkp-2015-2019-revisi-iii2.pdf

Badan Pusat Statistik. (2012). Berita Resmi Statistik. Diambil dari https://www.bps.go.id/pressrelease/2012/01/02/1/desember-2011-terjadi-inflasi-0-57persen.html

Badan Pusat Statistik. (2014). Berita Resmi Statistik. Diambil dari https://www.bps.go.id/pressrelease/2014/01/02/174/desember-2013-terjadi-inflasisebesar--0-55-persen.html

Badan Pusat Statistik. (2015). Berita Resmi Statistik. Diambil dari https://www.bps.go.id/pressrelease/2015/01/02/1094/inflasi-desember-2014-sebesar2-46-persen.html

Badan Pusat Statistik. (2016). Berita Resmi Statistik. Diambil dari https://www.bps.go.id/pressrelease/2016/01/04/1030/desember-2015-terjadi-inflasi0-96-persen.html

Badan Pusat Statistik. (2017). Berita Resmi Statistik. Diambil dari https://www.bps.go.id/pressrelease/2017/01/03/1284/desember-2016-inflasi-0-42persen.html

Badan Pusat Statistik. (2018). Berita Resmi Statistik. Diambil dari https://www.bps.go.id/pressrelease/2018/01/02/1409/desember-2017-terjadi-inflasisebesar-0-71-persen.html

Badan Pusat Statistik. (2019). Berita Resmi Statistik. Diambil dari https://www.bps.go.id/pressrelease/2019/01/02/1540/desember-2018-inflasi-sebesar0-62-persen--inflasi-tertinggi-terjadi-di-kupang-sebesar-2-09-persen-.html

Badan Pusat Statistik. (2020). Berita Resmi Statistik. Diambil dari https://www.bps.go.id/pressrelease/2020/01/02/1649/desember-2019-inflasi-sebesar0-34-persen--inflasi-tertinggi-terjadi-di-batam-sebesar-1-28-persen-.html

Banks, J., Blundell, R., \& Lewbel, A. (1997). Quadratic Engel Curves and Consumer Demand. 85(2), 298-306. Diakses pada 1 Juli 2020. Diambil dari http://links.jstor.org/sici?sici=0034-

6535\%28199711\%2979\%3A4\%3C527\%3AQECACD\%3E2.0.CO\%3B2-Z

Blow, L., Lechene, V., \& Levell, P. (2011). Improving the Measurement of Consumer Expenditures. In C. D. Carroll, T. F. Crossley, \& J. Sabelhaus (Ed.), NBER Working Paper Series. https://doi.org/10.7208/chicago/9780226194714.001.0001

Bochańczyk-Kupka, D. (2019). Necessity and Luxury Goods in Economics. NORDSCI International Conference Proceedings Business and Economics edition, 2, 259-265. Diakses pada 27 November 2019. https://doi.org/10.32008/nordsci2019/b2/v2/16

Boediono. (2012). Ekonomi Mikro Seri Sinopsis Pengantar Ilmu Ekonomi No. 1 (2 ed.). Yogyakarta: Badan Penerbit Fakultas Ekonomi UGM.

Booth, S., \& Smith, A. (2001). Food security and poverty in Australia -- challenges for dietitians. Australian Journal of Nutrition \& Dietetics, 58(3), 150-156. 24 November 2019. Diambil dari

http://search.ebscohost.com/login.aspx?direct=true \&db=cin20\&AN=106966090\&site= ehost-live 
Bopape, L. (2006). Heterogeneity of Household Food Expenditure Patterns in South Africa. 2006 Annual meeting, July 23-26, Long Beach, CA, 1-33. Diakses pada 27 Oktober 2019. Diambil dari http://ageconsearch.umn.edu/bitstream/21300/1/sp06bo03.pdf

Cox, T. L., \& Wohlgenant, M. K. (1986). Prices and Quality Effects in Cross-Sectional Demand Analysis. American Journal of Agricultural Economics, 68(4), 908-919. Diakses pada 9 Juli 2020. https://doi.org/10.2307/1242137

Crawford, M., \& Unger, R. (2004). Women and Gender: A Feminist Psychology (4th ed.). McGraw-Hill.

Deaton, A. (1987). Estimation of own- and cross-price elasticities from household survey data. Journal of Econometrics, 36(1-2), 7-30. Diakses pada 11 Juli 2020. https://doi.org/10.1016/0304-4076(87)90041-8

Deaton, A. (1990). Price elasticities from survey data. Extensions and Indonesian results. Journal of Econometrics, 44(3), 281-309. Diakses pada 10 Juli 2020. https://doi.org/10.1016/0304-4076(90)90060-7

Deaton, A., \& Muellbauer, J. (1981). Economics and Consumer Behaviour. In Journal of the Royal Statistical Society. Series A (General) (24th Print, Vol. 144). https://doi.org/10.2307/2981834

Faharuddin, N., Mulyana, A., \& Yunita, N. (2015). Analisis Pola Konsumsi Pangan di Sumatera Selatan 2013: Pendekatan Quadratic Almost Ideal Demand System. Jurnal Agro Ekonomi, 33(2), 121. Diakses pada 15 Juli 2020. https://doi.org/10.21082/jae.v33n2.2015.121-140

Fashogbon, A. E., \& Oni, O. A. (2013). Heterogeneity in Rural Household Food Demand and Its Determinants in Ondo State, Nigeria : An Application of Quadratic Almost Ideal Demand System. (January), 169-177. Diakses pada 26 Juli 2020. https://doi.org/10.5539/jas.v5n2p169

Gibson, J., \& Kim, B. (2019). Quality, quantity, and spatial variation of price: Back to the bog. Journal of Development Economics, 137, 66-77. Diakses pada 16 Juli 2020. https://doi.org/10.1016/j.jdeveco.2018.11.008

Harrigan, J. (2008). Food Insecurity, Poverty and The Malawian Starter Pack: Fresh Start or False Start? Food Policy, 33(3), 237-249. Diakses pada 4 Juli 2020. https://doi.org/10.1016/j.foodpol.2007.09.001

Hasibuan, H. S., Waromi, L. F., \& Utomo, S. W. (2018). Sustainable Food Security Strategy: Study of Land Suitability of Rice and Sago Commodity in Kampong Wapeko, Merauke District, Papua Province, Indonesia. E3S Web of Conferences, 68, 1-5. Diakses pada Juli 2020. https://doi.org/10.1051/e3sconf/20186804008

Hayat, N., Hussain, A., \& Yousaf, H. (2016). Food Demand in Pakistan: Analysis and Projections. South Asia Economic Journal, 17(1), 94-113. Diakses pada 16 Juli 2020. https://doi.org/10.1177/1391561415621826

Hoang, H. K. (2018). Analysis of food demand in Vietnam and short-term impacts of market shocks on quantity and calorie consumption. Agricultural Economics (United Kingdom), 49(1), 83-95. Diakses pada 18 Juli 2020. https://doi.org/10.1111/agec.12397

Hurlock, E. B. (2004). Development Psychology: A Life Span Approach (5th ed.).

Ivanic, M., \& Martin, W. (2008). Implications of higher global food prices for poverty in lowincome countries. Agricultural Economics, 39(SUPPL. 1), 405-416. Diakses pada 31 Juli 2020. https://doi.org/10.1111/j.1574-0862.2008.00347.x

Lewbel, A. (1996). Aggregation Without Separability: A Generalized Composite Commodity Theorem. American Economic Review, 86(3), 524-543. Diakses pada 29 Juli 2020. https://doi.org/10.2307/2118210

Mauludyani, A. V. R., Martianto, D., \& Baliwati, Y. F. (2008). Pola Konsumsi Dan Permintaan Pangan Pokok Berdasarkan Analisis Data Susenas 2005. Jurnal Gizi dan Pangan, 3(2), 101117. Diakses pada 8 Juli 2020. https://doi.org/10.25182/jgp.2008.3.2.101-117

Mekonnen, D. A., \& Gerber, N. (2017). Aspirations and food security in rural Ethiopia. Food Security, 9(2), 371-385. Diakses pada 3 Juli 2020. https://doi.org/10.1007/s12571-0170654-6

Mittal, S., \& Council, P. (2010). Application of the Quaids Model to The Food Sector in India. Journal of Quantitative Economics, 8(1), 42-54. Diakses pada 16 Juli 2020. Diambil dari https://www.researchgate.net/publication/254426537_Application_of_the_QUAIDS_m odel_to_the_food_sector_in_India 
Pangaribowo, E. H. (2010). Food Demand Analysis of Indonesian Households: Do They Eat Better or Smoke When They Get Richer? International Conference on Eurasian Economies 2010, 446-452. Diakses pada 24 Juli 2020. Diambil dari http://avekon.org/papers/205.pdf

Pangaribowo, E. H., \& Tsegai, D. (2011). Food Demand Analysis of Indonesian Household with Particular Attention to The Poorest. ZEF-Discussion papers on Development Policy No. 151, 1-38. Diakses pada 19 Juli 2020. Diambil dari https://www.econstor.eu/bitstream/10419/98222/1/770495125.pdf

Pemerintah Republik Indonesia. (2012). Undang-Undang Nomor 18 Tahun 2012 tentang Pangan. Diambil dari https://luk.staff.ugm.ac.id/atur/UU18-2012Pangan.pdf

Pindyck, R. S., \& Rubinfeld, D. L. (2018). Microeconomics (Ninth Edit; P. Banerjee, Ed.). Diambil dari http://93.174.95.29/_ads/B6CF884B5E1C4A29ACA6F3333956C402

Poi, B. P. (2012). Easy demand-system estimation with quaids. Stata Journal, 12(3), 433-446. Diakses pada 15 Juli 2020. https://doi.org/10.1177/1536867x1201200306

Pollak, R. A., \& Wales, T. J. (2015). Demographic Variables in Demand Analysis. Econometric Society, 49(6), 1533-1551. https://doi.org/10.2307/1911416

Rachman, H. P. S. (2001). Pola Konsumsi dan Permintaan Pangan di Kawasan Timur Indonesia (Institut Pertanian Bogor). Diambil dari https://repository.ipb.ac.id/bitstream/handle/123456789/813/2001hps.pdf?sequence= 4\&isAllowed=y

Ray, R. (1983). Measuring the Cost of Children: An Alternative Approach. Australian Economic Papers, 33(62), 120-138. Diakses pada 1 Juli 2020. https://doi.org/10.1111/j.14678454.1994.tb00011.x

Riptanti, E. W., Masyhuri, M., Irham, I., Suryantini, A., \& Mujiyo, M. (2018). The Development of Leading Food Commodities Based on Local Wisdom in Food-Insecure Area in East Nusa Tenggara Province, Indonesia. Applied Ecology and Environmental Research, 16(6), 78677882. Diakses pada 14 Juli 2020. https://doi.org/10.15666/aeer/1606_78677882

Ritonga, H. (1994). The Impact of Household Characteristics on Household Consumption Behavior: A Demand System Analysis on The Comsuption Behavior of Urban Households in the Province of Central Java, Indonesia. ProQuest Dissertations and Theses, 1-153. Diakses pada 18 Juli 2020.2 Diambil dari http://search.proquest.com/docview/304130077?accountid=13771

Setiana, R. (2019). Analisis Konsumsi Pangan dan Makronutrien Rumah Tangga di Provinsi Lampung. Universitas Gadjah Mada.

Siagian, E. S. G. (2013). Analisis Pola Konsumsi Pangan Rumah Tangga Indonesia, 2011. Universitas Gadjah Mada.

Stezhko, N. (2016). Global Indices in Assessment of The Global Food Problem and Its Impact Factor. Economic Annals-XXI, 161(9-10), 18-22. Diakses pada 29 Juli 2020. https://doi.org/10.21003/ea.V161-04

Sugiyanto, C. (2006). Permintaan Beras di Indonesia: Revisited. Jurnal Ekonomi \& Bisnis Indonesia (Fakultas Ekonomi dan Bisnis Universitas Gadjah Mada), 21(2), 138-155. Diakses pada 31 Juli 2020. https://doi.org/10.22146/jieb.6501

Sulistyaningrum, E. (2016). Household Food Demand in Response to Earthquake: A Linear Approximate Almost Ideal Demand System Approach. 90th Annual Conference of the Agricultural Economics Society, University of Warwick, England, 1-20. Diakses pada 19 Juli 2020. http://ageconsearch.umn.edu/record/236334/files/Eny_Sulistyaningrum_enypaper.pdf

Suryani, E., \& Rachman, H. P. S. (2008). Perubahan Pola Konsumsi Pangan Sumber Karbohidrat di Perdesaan. Jurnal Pangan, 52(17), 13-25. Diakses pada 11 Juli 2020. https://doi.org/10.33964/jp.v17i3.264

Tey, Yeong-sheng, J., Nasir, M., Zainalabidin, \& Mahir, A. (2009). Demand Analysis of Rice in Malaysia. Munich Personal RePEC Archive Demand analyses of rice in Malaysia, (15062), 1-21. Diakses pada 14 Juli 2020. Diambil dari https://mpra.ub.unimuenchen.de/15062/1/Demand_Analyses_of_Rice_in_Malaysia.pdf

Tian, X., \& Yu, X. (2013). The demand for nutrients in China. Frontiers of Economics in China, 8(2), 186-206. Diakses pada 6 Juli 2020. https://doi.org/10.3868/s060-002-013-0009-9

Ulubasoglu, M., Mallick, D., Wadud, M., Hone, P., \& Haszler, H. (2015). Food demand elasticities for Australia. Australian Journal of Agricultural and Resource Economics, 60(2),

18 | Volume 6. Nomor 12· Juni 2021 
177-195. Diakses pada 14 Juli 2020. https://doi.org/10.1111/1467-8489.12111

Umam, C. (2017). Analisis Pola Konsumsi Pangan Rumah Tangga Miskin di Indonesia Tahun 2011-2014: Pendekatan Quadratic Almost Ideal Demand System. Universitas Gadjah Mada. Varian, H. R. (2014). Intermediate Microeconomics A Modern approach (Ninth Edit; J.
Repcheck, http://93.174.95.29/main/1530000/358e73a2ed68128069b8749d4644e633/Hal R. Varian - Intermediate Microeconomics_ A Modern Approach-W. W. Norton \%26 Company \%282014\%29.pdf

Vu, L. H. (2009). Estimantion of Food Demand from Household Survey Data in Vietnam. Depocen Working Paper Series, 12, 1-26. Diakses pada 26 Juli 2020. Diambil dari http://depocenwp.org/upload/pubs/VuHoangLinh/Estimation of Food Demand from Household Survey Data in Vietnam_DEPOCENWP.pdf

$\mathrm{Vu}, \mathrm{L}$. H. (2020). Estimation and Analysis of Food Demand Patterns in Vietnam. Economies, $8(1), 1-17$. Diakses pada 4 Juli 2020. https://doi.org/10.3390/economies8010011

Wang, G. (2014). An Analysis of Structure Change of Food demand in China (The Arctic University of Norway). Diambil dari https://pdfs.semanticscholar.org/e573/b7aab0b7ced9461c1e3d7918678a410e4d38.pd $f$

Weber, R. (2015). Welfare Impacts of Rising Food Prices : Evidence from India. International Conference of Agricultural Economists: Agriculture In An Interconnected World, 1-26. Diakses pada 1 September 2020.

Widarjono, A. (2012). Food and Nutrient Demand in Indonesia (Oklahama State University). Diambil dari https://shareok.org/bitstream/handle/11244/6547/Department of Agricultural Economics_48.pdf?sequence $=1$

Widodo, T. (2004). Demand Estimation and Household's Welfare Measurement: Case Studies on Japan and Indonesia. 1-34. Diakses pada 26 Juli 2020. Diambil dari https://mpra.ub.uni-muenchen.de/78216/ 